\title{
Effect of Conceptual Change Oriented Instruction on Students' Conceptual Understanding and Decreasing Their Misconceptions in DC Electric Circuits
}

\author{
Erdal Taşlidere \\ Faculty of Education, Mehmet Akif Ersoy University, Burdur, Turkey \\ Email: etaslidere@mehmetakif.edu.tr
}

Received February $22^{\text {nd }}, 2013$; revised March $25^{\text {th }}, 2013$; accepted April $8^{\text {th }}, 2013$

\begin{abstract}
Copyright (C) 2013 Erdal Taşlıdere. This is an open access article distributed under the Creative Commons Attribution License, which permits unrestricted use, distribution, and reproduction in any medium, provided the original work is properly cited.
\end{abstract}

\begin{abstract}
The purpose of this study was twofold: first to investigate the effect of conceptual change oriented instruction accompanied by concept cartoon worksheet with simulation on students' conceptual understanding and second to remedy their misconceptions of direct current electric circuits. Participants were 139 pre-service science teachers from four intact classes. A quasi-experimental design was used in the study. The experimental group studied the concept with the application of concept cartoon worksheet and simulation, and the control group studied it with traditional instruction. Students' conceptual understanding and misconceptions were measured by a tree-tired misconception test. It was administered as pre-and-posttest. There was no significant difference between the means of pre-test scores of experimental and control groups. The main effect of treatment on post-test scores was examined via ANCOVA with pre-test scores used as covariate. The frequency of each misconception was calculated for both groups, from pre to post-tests regarding all tiers of items. The analysis yielded a significant treatment effect on students' post-test performances. The findings indicated that the conceptual change oriented instruction accompanied by concept cartoon worksheet and simulation is likely to be effective for conceptual understanding and decreasing most of students' misconceptions in direct current electric circuits.
\end{abstract}

Keywords: Conceptual Change; Conceptual Understanding; Concept Cartoon; Simulation; Electricity; Misconception

\section{Introduction}

Students' understanding of key concepts related to science topics has been an interesting research area and it has been investigated by researchers in physics education (Mulhall, McKittrick \& Gunstone, 2001). It is accepted that students come to the classes with a range of informal ideas and most of them are different from scientific conceptions (Hammer, 1996; Heller \& Finley, 1992; Jaakkola \& Nurmi, 2008; Treagust \& Duit, 2008). Learners' experiences of the world, the influence of their peers, the media and pre-instruction would lead them to develop these conceptions (Chu, Treagust \& Chandrasegaran, 2009; Fetherstonhaugh \& Treagust, 1992; Redish, Saul, \& Steinberg, 1998).

Students' incorrect pattern of response, informal ideas, nonscientific interpretations and conceptions leading to conflict with scientific view are called with different terms such as "preconceptions" (Celement, 1982), "misconceptions" (Ery1lmaz, 2002; Engelhardt \& Beichner, 2004), "alternative frameworks" (Driver \& Erickson, 1983) or "alternative conceptions" (Gilbert \& Watts, 1983). This paper will consider students' nonscientific conceptions as misconceptions. Misconceptions are stable cognitive structures and affect learners' understanding of scientific concepts; they are highly resistant to change (Hammer, 1996; Jaakkola \& Nurmi, 2008; Ronen \& Eliahu,
2000; Treagust \& Duit, 2008). Since science concepts are not presented with any ontological differentiation such as between process and material, the desired changes to students' ontologies are not generally succeeded in schools with traditional instruction (Treagust \& Duit, 2008). Hence, it is claimed that misconceptions cannot be remediated by traditional instruction (Celement, 1982; McDermott \& Shaffer, 1992). To promote conceptual understanding and eliminate learners' misconceptions, various conceptual change views of teaching and learning approaches were suggested (Treagust \& Duit, 2008; Vosniadou, 2007). These models and strategies were derived from Kuhn's philosophy of science and Piaget's cognitive developmental theory (Zhou, 2010).

\section{Conceptual Change Approach}

Conceptual change views of teaching processes have played crucial role both in research of teaching and learning since the late 1970s (Treagust \& Duit, 2008). Various models and strategies (Dole \& Sinatra, 1998; Gregoire, 2003; Hynd \& Alvermann, 1986; Posner, Strike, Hewson, \& Gertzog, 1982; Roth, 1985; Zhou, 2010) were proposed to facilitate teaching for conceptual change and most of them were based on or closely related to Posner et al.'s model (Smit, Blakeslee, \& Anderson, 1993). 
In the current study, the classical conceptual change approach, suggested by Posner et al. (1982), was handled and the study was carried on with this model. Posner et al. proposed a conceptual change instruction to help learners in transforming preconceptions into scientific conceptions. It involves teacher making students' preconceptions explicit before designing a teaching approach which includes ideas that are inconsistent with students' existing conceptions (Treagust \& Duit, 2008). According to Posner et al., four conditions: 1) dissatisfaction of learner, 2) intelligibility, 3) plausibility, and 4) fruitfulness of new conception must be satisfied for the conceptual change. Learners must first encounter with pre-existing conception to consider a new one. If the new conception does not produce dissatisfaction, then it may be assimilated alongside the old one. If new and old conceptions reveal their incompatibility, then two outcomes may happen; if new one succeeds higher status than the previous one, then accommodation or conceptual exchange may occur, otherwise no conceptual exchange proceeds (Hewson, 1982; Treagust \& Duit, 2008).

Intelligibility requires constructing a coherent representation of a theory and understanding of the meaning of conception. A plausible conception must be believable in addition to the learners' knowing what it means. Fruitfulness is the capacity of the conception to help learners in solving other problems or to suggest new research directions (Treagust \& Duit, 2008).

In the literature, it was reported that the instructions developed by considering conceptual change approach are effective than the traditional approaches in considering the cognitive outcomes (Bryce \& MacMillion, 2005; Çalik, Okur \& Taylor, 2011; Çelikten, Ertepınar, \& Geban, 2012; Guzetti, Snyder, Glass, \& Gamas, 1993; Hynd \& Alvermann, 1986; Piquette \& Heikkinen, 2005; Roth, 1985; Treagust \& Duit, 2008). Treagust and Duit (2008) reported that embedding conceptual change strategies in conceptual change supporting learning environments would result in efficient conceptual understanding. Hence, in this study, the classical conceptual change oriented instruction aimed to be succeeded via concept cartoon worksheets and simulations.

\section{Concept Cartoon Worksheet}

A concept cartoon is an educational tool that expresses scientific problems related to daily life via character cartoons and present different views related to everyday life (Keogh, Naylor, \& Wilson, 1998; Keogh \& Naylor, 2000). It was developed by Brenda Keogh and Stuart Naylor in 1992 to develop an innovative teaching and learning strategy that took account of constructivist views of learning (Keogh \& Naylor, 1999). Two or more characters discuss problems or express diverse opinions about the science. Both scientific and alternative conceptions take part in the discussion (Ekici, Ekici, \& Aydın, 2007). It can be prepared in both poster and worksheet form and can be used either as instructional material or teaching method in science courses (Kabapınar, 2009).

Worksheet is an educational tool that guides students' learning. Concept cartoon worksheet is a kind of worksheet that is enriched with concept cartoons. It includes cartoon characters, instructional directions, follow up questions and various activities. It specifies what students will do and encourage learners to participate in classroom activities.

In the literature, there exist studies about concept cartoons (Birisci et al., 2010; Ekici et al., 2007; Kabapınar, 2009; Keogh et al., 1998; Keogh \& Naylor, 2000; Stephenson \& Warwick,
2002) or concept cartoon worksheets (Atasoy, 2008; Burhan, 2008; Gürses, Akdeniz, \& Atasoy, 2006; Taşlıdere, 2013). These studies generally administered either of concept cartoons or their worksheets as tools for teaching and learning in classroom and investigated their effectiveness on students' conceptual understanding and achievements. The results indicated that use of them were effective for finding out pupils' ideas (Keogh et al., 1998), and provides powerful stimulus for learners to focus their attention on constructing meaningful explanations (Keogh \& Naylor, 1999; Stephenson \& Warwick, 2002).

\section{Simulation}

A simulation is a computerized version of a model that is run over a period of time to study the implications of the predefined interaction (Başer, 2006). Simulation based learning is generally considered as an alternative approach to expository instruction or to real hands-on lab exploration (Ronen \& Eliahu, 2000). It allows learners to directly manipulate initial conditions and immediately see the impact (Zacharia, 2005). It was argued that teaching physics via simulations make the content more easily understandable (Jaakko \& Nurmi, 2008), and provides constructive feedback to remediate their misconceptions (Ronen \& Eliahu, 2000).

Research studies have reported potentially positive impact of simulations on the developments of conceptual understanding, attitudes, cognitive and metacognitive skills and instructional approaches (Bakaç, Taşoğlu, \& Akbay, 2011; Başer, 2006; Bryan \& Slough, 2009; Cox, Belloni, \& Melissa, 2003; Jaakkola \& Nurmi, 2008; Ronen \& Eliahu, 2000). Using simulations actively within curriculum enhances learning activities (Zacharia, 2005).

\section{Study Topics}

The current research was conducted on direct current electric circuit which is highly abstract and complex (Mulhall et al., 2001; Taber, Trafford \&Teresa, 2006). Students at all ages and levels have many learning difficulties and misconceptions even after formal instructions (Engelhardt \& Beichner, 2004; Jaakkola \& Nurmi, 2008; McDermott \& Shaffer, 1992; Mulhall et al., 2001; Peşman \& Eryılmaz, 2010). Hence, over the past two decades, learners' understanding of electricity, ranging from primary school to the university level, has been investigated in several studies (Ateş \& Polat, 2005; Mulhall et al., 2001; Ronen \& Eliahu, 2000).

\section{Students Misconceptions Concerning Simple Electric Circuits}

There is an extensive literature on students' conceptual understanding of the DCEC. The common misconceptions in the related literature without giving the details of individual studies are;

The Sink Model (M1): Only a single wire connection between an electrical device and power supply is enough to run the electrical device (Chambers \& Andre, 1997; Peşman \& Eryılmaz, 2010; Sencar \& Ery1lmaz, 2004).

The Attenuation Model (M2): Electric current travelling in one direction decreases gradually due to consumption of current by devices (McDermott \& Shaffer, 1992; Peşman \& Eryılmaz, 2010; Sencar \& Eryılmaz, 2004; Shipstone, 1988; Shipstone et al., 1988). 
The Shared Current Model (M3): Electric current is shared equally by devices within the circuit (Sencar \& Eryllmaz, 2004; Shipstone, 1988).

The Sequential Model (M4): Any change at a point in an electric circuit affects the circuit forward in the direction of the current, not backward (Dupin \& Johsua, 1987; Engelhardt \& Beichner, 2004; McDermott \& Shaffer, 1992; Peşman \& Ery1lmaz, 2010; Sencar \& Eryılmaz, 2004; Shipstone, 1988).

The Clashing Current Model (M5): Positive and negative electricity from the battery meet at an electrical device and clashing of them causes device to run (Chambers \& Andre, 1997; Peşman \& Eryılmaz, 2010; Sencar \& Eryılmaz, 2004).

The Empirical Rule Model (M6): The bulb which is farther away from the power supply is dimmer than the closer bulbs (Heller \& Finley, 1992; Peşman \& Ery1lmaz, 2010; Sencar \& Eryılmaz, 2004).

The Short Circuit Misconception (M7): Wires in the electric circuit with no electrical devices are ignored when analyzing the circuit (Chambers \& Andre, 1997; Peşman \& Eryılmaz, 2010; Sencar \& Eryılmaz, 2004).

The Power Supply as Constant Current Source (M8): Power supply within the circuit provides constant electrical current rather than electrical energy (Cohen, Eylon, \& Ganiel, 1983; Dupin \& Johsua, 1987; McDermott \& Shaffer, 1992; Heller \& Finley, 1992; Peşman \& Eryılmaz, 2010; Sencar \& Eryılmaz, 2004; Shipstone, 1988; Shipstone et al., 1988).

The Parallel Circuit Misconception (M9): A resistor is an obstacle to current flow, assuming any increase in the number of parallel connected resistors result in the increase of the total resistance (Chambers \& Andre, 1997; Cohen et al., 1983; McDermott \& Shaffer, 1992; Peşman \& Eryılmaz, 2010; Sencar \& Eryılmaz, 2004).

Local Reasoning (M10): Students focus their attention upon one point in the circuit and ignore what is happening elsewhere. The local part is focused on instead of global analysis (Cohen et al. 1983; Peşman \& Eryılmaz, 2010; Sencar \& Eryılmaz, 2004; Shipstone et al., 1998).

Current Flow as Water Flow (M11): Electric current flows within a wire like water flow in a pipe; most of the current goes straight and less amounts of it goes from the wire which is not straight (Peşman \& Eryılmaz, 2010).

In the literature, while conceptual change approaches have been advocated for helping students deal with conceptual understanding and misconceptions, hardly any of the research has examined the effectiveness of the conceptual change oriented instruction accompanied by concept cartoon worksheet and simulation, on students' conceptual understanding and remediating participants' misconceptions in the DCEC.

\section{Method}

\section{Research questions}

The following research questions framed this study:

1) What is the effect of conceptual change oriented instruction accompanied by concept cartoon worksheet and simulation on pre-service science teachers' post-test scores (PSTT) in the DCEC when their pre-test scores (PRET) are controlled.

2) How do the proportions of the misconceptions change in experimental and control groups after treatments?

\section{Population and Sample}

The population of the study consists of all 397 pre-service science teachers studying at an education faculty of Government University in Turkey, 139 of which participated in the study. Two classes (72 students) were assigned randomly as experimental groups and the remaining two (67 students) as control groups, making the sample $35 \%$ of the population. Participants' ages ranged from 18 to 24 years. Table 1 shows students' gender and age separated by group.

\section{Measuring Tools}

To measure the students' conceptual understanding and misconceptions in the DCEC, a Three-Tier Simple Electric Circuit Misconception Test (TTMT) was used. The test was developed by Peşman and Ery1lmaz (2010) and consists of 12 questions, measuring 11 misconceptions in the DCEC. The characteristic of the TTMT is that, each item has three-tiers; the first tier is a conventional multiple-choice question with at least two choices, the second tier presents some reasons for the given answer to the first tier and the third tier examines if students are confident about their answers for the previous first two tiers. A sample question from the TTMT was given in Figure 1.

The main reason for using the TTMT is that the classical multiple-choice instruments cannot reveal what reasons are beyond the students' choice selection. Hence, the three-tier test is the best at eliciting the most actual percentages of student misconception (Hasan, Bagayoko, \& Kelley, 1999). Peşman and Eryılmaz (2010) collected the evidences for the validity and reliability of the TTMT. They reported the reliability coefficient of Croanbach alpha as 0.55 . In the current study the reliability analysis was also re-conducted over the PSTT and it was calculated as 0.81 .

\section{Development of Concept Cartoon Worksheets}

The literature concerning the DCEC was searched and students' possible misconceptions were determined. Five concept cartoon worksheets were prepared keeping misconceptions in mind. Each worksheet has a title, context, discussion and activity sections. The context presents a scientific problem and at least two characters are suggesting correct or alternative responses. A blank area was placed under characters for students to write their individual reasoning about why the character is likely correct before the discussion session. Activity sessions include follow up questions, use of computerized simulations and discussions of the practical applications of concept.

The developed concept cartoon worksheets were checked by two instructors and one research assistant. Regarding their feedback, relevant changes were completed. The worksheets were applied in three different higher classes as a pilot study. The deficiencies in worksheets and in their application proce-

Table 1.

Number of students within groups according to their gender and age.

\begin{tabular}{cccccccc}
\hline \multicolumn{7}{c}{ Experimental Group } \\
\hline \multicolumn{7}{c}{ Gender } & \multicolumn{7}{c}{ Age } & Total \\
\hline $\mathrm{N}$ & 20 & 52 & 11 & 33 & 21 & 7 & 72 \\
\hline $\mathrm{N}$ & 18 & 49 & 9 & 32 & 19 & 7 & 67 \\
Total & 38 & 101 & 20 & 65 & 40 & 14 & 139 \\
\hline
\end{tabular}


In Figure 5, an electrical circuit is given. Then, Bulb B is inserted into the circuit as shown in Figure 6 Answer Question 5 using this information.

1

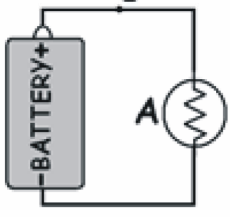

Figure 5

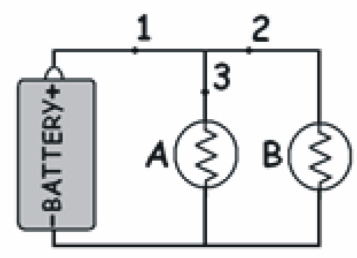

Figure 6

5.1. Compare the amount of current at point 1 in Figure 5 with the amount of current at Point 1 in Figure 6.

a) More in Figure 5 .

b) More inFigure 6 .

c) Equal in the both figures.

5.2. Which of the followings is the reason of your answer to the previous question?

a) Because there are two bulbs in Figure 6, the total resistance is more.

b) In Figure 6, the current coming from the battery is divided into two branches.

c) While the battery supplies one bulb with current in Figure 5, it supplies two bulbs in Figure 6.

d) The total resistance is smaller in the circuit in Figure 6.

e) The currents have not been divided into branches in both of the figures.

5.3. Are you sure about your answers given to the previous two question?

a) Sure.

b) Not sure.

Figure 1.

Sample question from the TTMT.

dures were determined and the necessary corrections were made. One of them is shown in Figure 2.

\section{Computerized Simulation}

In the study, the Circuit Construction Kit simulation program (CCKP) was used from the University of Colorado's Physics Education Technology website:

http://phet.colorado.edu/en/simulation/circuit-construction-kit-dc. The CCKP allows users to construct various circuits easily by dragging wires, bulbs and resistors.

\section{Treatment}

This study was conducted over a three-week treatment period. The topics related to the DCEC were covered as part of regular classroom curriculum in General Physics-II lesson and includes current, power supply, electromotive force, resistors, energy, power, electric circuits, and internal structure of measuring tools, uses of electricity and safety rules. Students in both the experimental and control groups were exposed to the same content. Duration of the lessons was four 45 -minute periods per week.

In the experimental group, the treatment was conducted regarding the conceptual change strategy developed by Posner et al. (1982). As previously reported, Posner et al. proposed four conditions for conceptual change: dissatisfaction, intelligibility, plausibility, and fruitfulness. At the beginning of the lessons, the developed worksheets were distributed to the students. They read the question given in the context and predict the correct response over the characters. After that, students wrote why the chosen character is likely correct into the blank area. With these, it was aimed to activate and get students' pre-conceptions. Then, they were encouraged to express and discuss their ideas to convince other students in classroom environment. Upon discussions, students were convinced about the correctness or fallacy of their idea via computer simulation to promote dissatisfaction. By observing correct model via simulation, they were convinced and the intelligibility was satisfied. Simulations and follow up supportive scientific explanations helped students resolve confusion and understand the concept. These provided the plausibility condition. For the fruitfulness condition, the instructor presented and discussed the real life applications of the concepts.

The sample treatment conducted via "Parallel Circuit Model", given in Figure 2, and simulation was presented below briefly. The instructor distributed the worksheets to the students. Upon reading the context and the question, each student determined his/her favorite character and wrote why the character is likely correct. This process continued for approximately five minutes. Afterwards, students were told to advocate their ideas and convince their friends. During the discussions, the M9 and M8 were detected as in previous studies (Cohen et al., 1983; Dupin \& Johsua, 1987; Heller \& Finley, 1992; McDermott \& Shaffer, 1992; Shipstone, 1988). Upon it, the instructor opened the CCKP; first constructed and ran the simulation of the Circuit X 


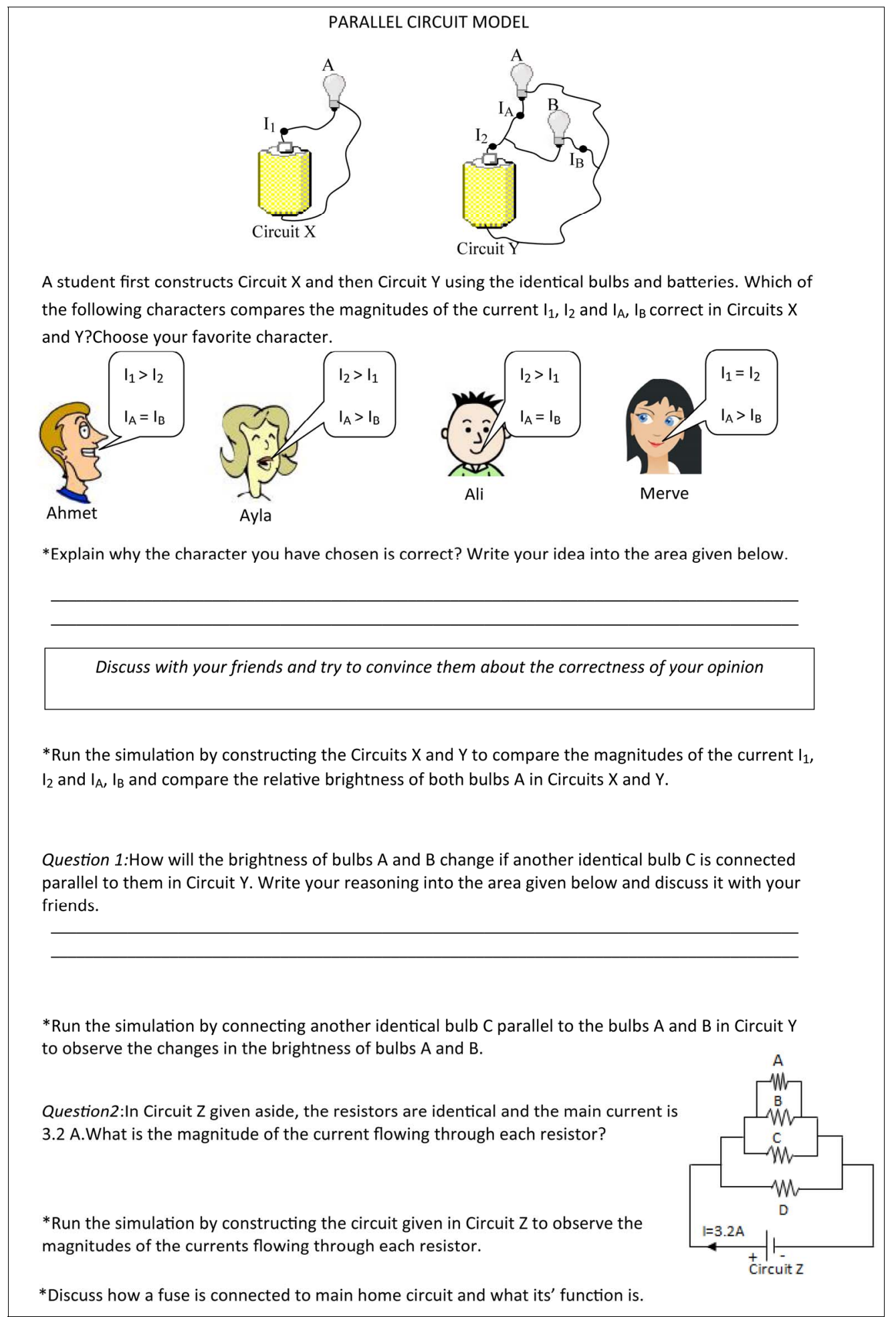

Figure 2.

Sample concept cartoon worksheet.

and then constructed the Circuit Y near the first one, and finally ran both simulations. Upon running simulations, the scientific explanations were commented by instructor. Figure $\mathbf{3}$ shows the constructed Circuits X and Y on the CCKP.

Then, Question 1 was asked; similarly students wrote and discussed their ideas, afterward the simulation was run and required explanations were commented. Asking Question 2 exposed another difficulty; the graphical representation of this question disguised the symmetry existing between the four bulbs. Most of students gave "splitting-in-two" response. They 


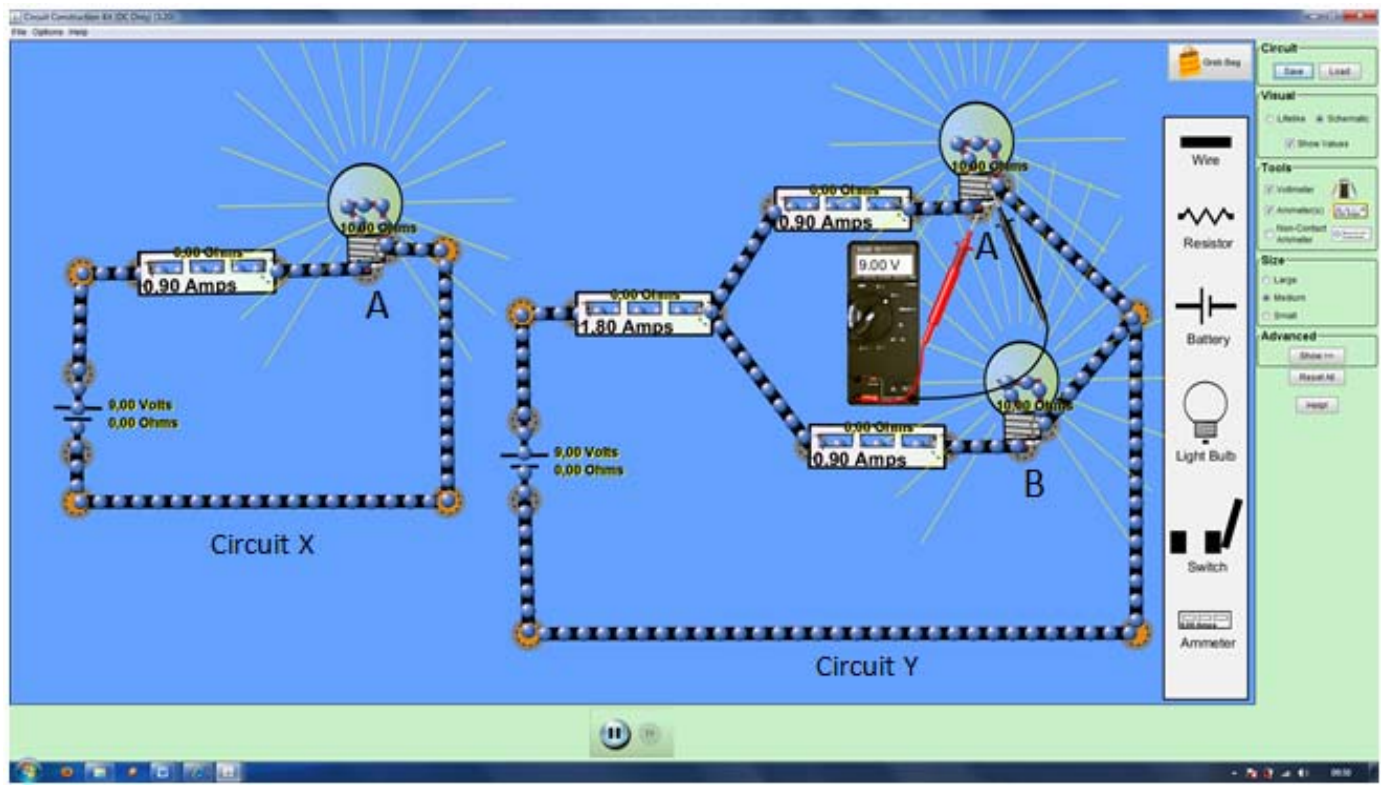

Figure 3.

Constructed Circuits $\mathrm{X}$ and $\mathrm{Y}$ on the CCKP.

exposed that the main current is divided into two equal parts at each successive junction as in previous study (Shipstone et al., 1988). Upon students' responses, the instructor opened the CCKP and constructed the concerning circuit first by connecting resistor $\mathrm{D}$ and running the simulation, second by connecting the resistor $\mathrm{C}$ and running the simulation and so on. Meanwhile scientific explanations were also exposed. Finally the electric fuse, its' function and connection of it to the main home circuit were discussed. For the whole study, four more concept cartoon worksheets were administered by using computerized simulations.

On the other hand, the control group students received traditional instruction involving lessons using lecture method to learn the corresponding concepts. The traditional instruction relied on instructors' explanations without consideration of the learners' misconceptions. The instructor defined the related concepts, explained the facts, and solved the questions in their books. Meanwhile, the students took notes through the lessons. The instructor did not use any of the activities and strategies developed for the experimental group.

\section{Procedure}

A quasi-experimental design was used in the study. The study began with the administration of the TTMT to all study groups as pre-test. For a three-week treatment period, the experimental group students were instructed with the conceptual change oriented instruction accompanied by concept cartoon worksheets and simulations, and the control group students received only traditional instruction. After the treatment period, the TTMT was administered as post-test to all groups.

\section{Results}

\section{Scores Obtained from the TTMT}

Students' test scores were calculated according to the correctness of each item considering all three tiers. If students' answers for the first two tiers are correct and he/she is sure about the correctness of the previous two selections at the third tier, then the item was scored as 1 point. Otherwise, the item was scored as 0 point. Total score was calculated by summing the score of each item.

Total scores could range from 0 to 12 points; in which higher score denotes strong conceptual understanding and the lower score denotes weak conceptual understanding. Table 2 shows the descriptive results obtained from the PRET to PSTT for both experimental and control groups. As seen from the table, experimental group students gained a mean increase of 4 points and control group students gained a mean increase of 1.1 points from the PRET to PSTT.

\section{Percentage of Misconceptions}

The percentages for each of the 11 misconceptions were calculated considering all three tiers for both groups before and after instructions. The PRE and PST denote the percentage of misconceptions before and after instructions respectively as in Table 3. The percentage values were calculated based on the misconception table reported by Peşman and Eryılmaz (2010). For example, according to this table the M8 is measured by Item 5 of the TTMT (5.1a, 5.2a, 5.3a). If the student chose 5.1a, $5.2 \mathrm{a}$, and $5.3 \mathrm{a}$ respectively, then the item 5 was coded as " 1 ". This means that student holds the M8. For all other possibilities, item 5 was coded as " 0 ", accepting that student has no misconception of the M8. Upon these coding, the percentages were calculated for each of 11 misconceptions.

As seen from Table 3, in both groups the percentage of students having misconceptions for each of 11 misconceptions are almost similar considering the pre-test. The M4, M7, M9 and M10 seem to be serious misconceptions based on the Caleon and Subramaniam (2010) explanation which states that the percentage of misconception above $10 \%$ should be considered as serious misconceptions. Among the above, the percentage of M9 seems to fall under $10 \%$ after instructions in both groups. 
Table 2.

Basic descriptive statistics for the PRET and PSTT mean scores by treatment.

\begin{tabular}{cccccc}
\hline & & \multicolumn{2}{c}{ PRET } & \multicolumn{2}{c}{ PSTT } \\
\cline { 3 - 6 } Treatments & N & Mean & SD & Mean & SD \\
\hline Experimental & 72 & 4.0 & 2.5 & 8.0 & 2.6 \\
Control & 67 & 3.3 & 1.9 & 4.4 & 2.1 \\
Total & 139 & 4.6 & 2.5 & 6.3 & 2.9 \\
\hline
\end{tabular}

Table 3.

Percentage of misconceptions from Pre-to-Post TTMT.

\begin{tabular}{ccccc}
\hline \multirow{2}{*}{ Misconceptions } & \multicolumn{2}{c}{ Experimental Group } & \multicolumn{2}{c}{ Control Group } \\
\cline { 2 - 5 } & PRE & PST & PRE & PST \\
\hline M1 & 4.9 & 4.9 & 6.0 & 3.0 \\
M2 & 4.2 & 4.2 & 4.5 & 1.5 \\
M3 & 6.5 & 12.0 & 7.9 & 5.5 \\
M4 & 35.4 & 20.2 & 32.8 & 45.6 \\
M5 & 2.8 & 1.4 & 5.5 & 4.5 \\
M6 & .0 & .0 & .0 & .0 \\
M7 & 21.3 & 11.6 & 21.9 & 29.9 \\
M8 & 1.4 & 1.4 & 0.0 & 3.0 \\
M9 & 11.8 & 3.5 & 10.5 & 9.0 \\
M10 & 27.8 & 13.0 & 27.9 & 33.8 \\
M11 & 2.3 & 2.8 & 9.5 & 5.5 \\
Average & 10.8 & 6.8 & 11.5 & 12.8 \\
\hline
\end{tabular}

In the experimental group, the percentage values for the M4, M7 and M10 seem to decrease, but they increased in control group interestingly. When the average of eleven misconceptions' percentage values are considered, it seems that the mean value decreased by $4.0 \%(10.8-6.8)$ for experimental and increased by $1.3 \%$ for control groups even after treatments.

\section{Inferential Results}

To determine whether a possible pre-existing difference and any covariate could affect the PSTT, the groups' PRET mean scores were analyzed. ANOVA techniques were used to determine if PRET mean scores differed among the groups. The results revealed no statistical significance $(\mathrm{F}(1,120)=3.1, p$ $=.08)$. This denotes that the groups were similar at the beginning of the study. Further, the relationship between the PRET and PSTT was investigated using Pearson product-moment correlation coefficient. The analysis indicated that there was a medium correlation between two variables, $\mathrm{r}=.438, \mathrm{n}=139, \mathrm{p}$ $<.0005$ (Pallant, 2007). Hence, the PRET was determined as covariate of the study for the following inferential analysis. A one-way between-groups analysis of covariance (ANCOVA) was conducted to assess the two instructions on PSTT. Preliminary checks were conducted to ensure that there was no violation of the assumptions of normality, linearity, homogeneity of variances, homogeneity of regression slopes and reliably measure of covariates. After adjusting PRET, it was found a significant treatment effect on the PSTT $(F(1,136)=77.3, p$ $=.000$, partial eta squared $=.36)$. The calculated effect size for the treatment was also found as .37 (Pearson's correlation coefficient). Table 4 shows the ANCOVA results.
Table 4.

ANCOVA table for the PSTT means scores by treatments.

\begin{tabular}{cccccccc}
\hline Source & SS & Df & MS & F & P & ES & OP \\
\hline $\begin{array}{c}\text { Corrected } \\
\text { Model }\end{array}$ & 575.6 & 2 & 287.8 & 64.0 & .000 & .49 & 1.000 \\
Intercept & 722.9 & 1 & 722.9 & 160.8 & .000 & .54 & 1.000 \\
PRET & 147.9 & 1 & 147.9 & 32.9 & .000 & .19 & 1.000 \\
Treatment & 347.5 & 1 & 347.5 & 77.3 & .000 & .36 & 1.000 \\
Error & 611.5 & 136 & 4.5 & & & & \\
Total & 6645.0 & 139 & & & & & \\
Corrected & 1187.2 & 138 & & & & & \\
Total & & & & & & & \\
\hline
\end{tabular}

Note: $\mathrm{R}$ Squared $=.485$ (Adjusted R Squared $=.477)$.

\section{Discussion}

The current study investigated the effects of the conceptual change oriented instruction accompanied by cartoon worksheet and simulation on pre-service science teachers' conceptual understanding and decreasing their misconceptions in the DCEC. The observed power was calculated as 1 and effect size was found as large, which denotes that $36 \%$ of the variance of PSTT was explained by treatment. These could suggest that the study has practical significance as well as theoretical significance.

The individual studies conducted by concept cartoons (Birisci et al., 2010; Ekici et al., 2007; Kabapınar, 2009; Keogh et al., 1998; Keogh \& Naylor, 2000; Stephenson \& Warwick, 2002) and concept cartoon worksheets (Atasoy, 2008; Burhan, 2008; Gürses et al., 2006; Taşlidere, 2013) reported positive effects of using them in science education. In the same way, the studies conducted on simulations (Başer, 2006; Jaakko \& Nurmi, 2008; Ronen \& Eliahu, 2000; Zacharia, 2005) reported also positive effects of using them in science education too. Since this study consisted of both of the use of concept cartoon worksheet and computerized simulation to promote conceptual change, the outcomes supported the findings of the previous conceptual change studies (Bryce \& MacMillion, 2005; Çalik et al., 2011; Çelikten et al., 2012; Guzetti et al., 1993; Hydn \& Alvermann, 1986; Roth, 1985; Piquette \& Heikkinen, 2005; Treagust \& Duit, 2008).

The statistical analysis indicated that the experimental group significantly outperformed the control group in understanding of key aspects and concepts involved in the DCEC. This success can be attributed both to the careful conduction of conceptual change strategies via concept cartoon worksheets with simulations and to the active participation of experimental group students into the teaching learning environment. As constructivist approach (Powell \& Kalina, 2009) implied, students were active both socially and cognitively throughout the study and they had enough time to express their preconceptions. As Keogh and Naylor (1999) reported, discussions led to disequilibrium and students had conceptual conflict. Running simulations visualized the theoretical circuit conceptions and provided constructive feedback for the intelligibility. The follow up questions further increased participants' curiosity. After making certain configurations with the circuit, students observed the effects and got instant feedback. The scientific explanations and the feedback encouraged students to think critically and scientifically for the plausibility. Finally, the presentation and dis- 
cussions of the daily life applications of the electricity reinforced students' learning for the fruitfulness. In conclusion, the strategies offered by Posner et al. (1982) were successfully conducted for each the five concept cartoon worksheet and simulations.

On the other hand, students in control group just followed the lectures and solved the questions in their books. Students were just passive listeners following the instructor. Hence, they did not apply their preconception to different contexts offered as in concept cartoon worksheets, and did not discuss their ideas to influence other students. Since they did not experience simulation, they had difficulties visualizing the theoretical electric concepts. They mainly focused on the identification of terms and equations that require problem solving and less conceptual restructuring.

The current study also investigated the percentages of misconceptions before and after instructions for experimental and control groups. In line with the previous studies (Engelhardt \& Beichner, 2004; Jaakkola \& Nurmi, 2008; McDermott \& Shaffer, 1992; Mulhall et al., 2001; Peşman \& Ery1lmaz, 2010), this study indicated that most of the pre-service science teachers in both groups had initially misconceptions. After treatments, although the ANCOVA denoted significant difference between the mean scores of the PSTT favoring experimental groups, the frequency analysis denoted that there are still serious misconceptions (M4, M7 and M10) in both groups. As previous studies (Hammer, 1996; Jaakkola \& Nurmi, 2008; Ronen \& Eliahu, 2000; Treagust \& Duit, 2008) claimed, this study proved that misconceptions are highly resistant. The high percentages of the M4 and M10 are consistent because they are conceptually similar misconceptions. Both are detecting students who are focusing their attentions upon one point where any change is performed or further away from that point not backward in the circuit. Similar ones were also detected as in previous studies (Cohen et al., 1983; Dupin \& Johsua, 1987; Engelhardt \& Beichner, 2004, McDermott \& Shaffer, 1992; Peşman \& Eryılmaz, 2010; Sencar \& Eryılmaz, 2004; Shipstone, 1988; Shipstone et al., 1998).

The analysis denoted that, the conceptual change oriented instruction seemed to decrease the percentages of misconceptions except the M3 in experimental groups, ignoring the M11 due to it' small increase. But, traditional instruction seemed to increase the M4, M7, M8 and M10 in control groups. As recent studies (Chu et al., 2009; Fetherstonhaugh \& Treagust, 1992; Redish et al., 1988) reported, the traditional instruction conducted in the current study resulted in the development of some of the misconceptions. Hence a more special attention should be given to them. But in general, if the average percentage values of 11 misconceptions are considered, it can be concluded that conceptual change oriented instruction seems to be effective in decreasing the frequency of students holding misconceptions rather than removing completely than the traditional instruction.

In the current study, a treatment was developed via concept cartoon worksheet and simulation. They were both used together and complemented each other. Hence, it is difficult to determine which one is more affective for conceptual understanding and/or for decrease of misconceptions. And also it was not the scope of current study. But relative effectiveness of concept cartoon worksheets and simulation for conceptual understanding and or for decreasing misconceptions would be investigated by further studies in the DCEC or other subject matters.

There are various possible threats that most of the experimental studies experience. The standardizing conditions and the procedures, the ANCOVA model, three-week treatment period, and the research design of the study were used as measures to control the internal validity threats for the study. For the external validity of the study, I can claim that the study was conducted in a university in which the physical conditions were same. Treatments and all testing procedures took place in ordinary classrooms. The generalizability of the results was not a problem, because 139 students comprised approximately $35 \%$ of the population. Hence, the results can be generalized to the university where the study was conducted.

There are also some limitations for the study. First of all, this study was conducted in one Government University, and hence the results can be generalized to this university. Second, students' misconceptions in the DCEC were measured via reliable and valid test of the TTMT and the results were limited with the data obtained from it. Third, students' PSTT scores were calculated regarding all three tiers of the items

\section{Conclusion}

The use of concept cartoon worksheet with simulation to promote conceptual change in science education may be of particular value to pre-service science teachers. Efforts to increase future science teachers' conceptual understanding and remediating their misconceptions by conceptual change oriented instruction accompanied by concept cartoon worksheets and simulations are of particular importance in that they may result in effective science instruction, thus affecting large numbers of future science learners. This study would enable future science teachers to define the development and application of concept cartoon worksheet with simulation and compare it with other alternative teaching methods.

\section{REFERENCES}

Atasoy, Ş. (2008). Researching effectiveness of worksheets developed to remedying students teachers' misconceptions about Newton's Laws of Motion. Unpublished Doctoral Dissertation, Trabzon: Karadeniz Technical University.

Ateş, S., \& Polat, M. (2005). The effects of learning cycle method on removing misconceptions related to electric circuits. Hacettepe University Journal of Education, 28, 39-47.

Bakaç, M., Taşoğlu, A. K., \& Akbay, T. (2011). The effect of computer assisted instruction with simulation in science and physics activities on the success of student: Electric current. Eurasion Journal of Physics and Chemistry Education, 1, 34-42.

Baser, M. (2006). Effects of conceptual change and traditional confirmatory simulations on pre-service teachers' understanding of direct current circuits. Journal of Science Education and Technology, 15, 367-381. doi:10.1007/s10956-006-9025-3

Birisci, S., Metin, M., \& Karakas, M. (2010). Pre-service elementary teachers' views on concept cartoons: A sample from Turkey. MiddleEast Journal of Scientific Research, 5, 91-97.

Bryan, J. A., \& Slough, S. W. (2009). Converging lens simulation design and image predictions. Physics Education, 44, 264-275. doi:10.1088/0031-9120/44/3/006

Bryce, T., \& MacMillan, K. (2005). Encouraging conceptual change: The use of bridging analogies in the teaching of action-reaction forces and the 'at rest' condition in physics. International Journal of Science Education, 27, 737-763. doi:10.1080/09500690500038132

Burhan, Y. (2008). Developing worksheets enriched by concept cartoons concerning the acid-base concepts. Unpublished Master Thesis, Trabzon: Karadeniz Technical University. 
Caleon, I., \& Subramaniam, R. (2010). Development and application of a three-tier diagnostic test to assess secondary students' understanding of waves. International Journal of Science Education, 32, 939961. doi:10.1080/09500690902890130

Çalık, M., Okur, M., \& Taylor, N. (2011). A comparison of different conceptual change pedagogies employed within the topic of "sound propagation”. Journal of Science Education and Technology, 20, 729-742. doi:10.1007/s10956-010-9266-Z

Çelikten, O., Ertepınar, H., \& Geban, Ö. (2012). The effect of the conceptual change oriented instruction through cooperative learning on 4th grade students' understanding of earth and sky concepts. Science Education International, 23, 84-96.

Chambers, S. K., \& Andre. T. (1997). Gender, prior knowledge, interest, and experience in electricity and conceptual change text manipulations in learning about direct current. Journal of Research in Science Teaching, 34, 107-123.

doi:10.1002/(SICI)1098-2736(199702)34:2<107::AID-TEA2>3.0.C $\underline{\mathrm{O} ; 2-\mathrm{X}}$

Chu, H.-E., Treagust, D. F., \& Chandrasegaran, A. L. (2009). A stratified study of students' understanding of basic optics concepts in different contexts using two-tier multiple-choice items. Research in Science \& Technological Education, 27, 253-265. doi:10.1080/02635140903162553

Clement, J. (1982). Students' preconceptions in introductory mechanics. American Journal of Physics, 50, 66-71. doi:10.1119/1.12989

Cohen, R., Eylon, B., \& Ganiel, U. (1983). Potential difference and current in simple electric circuits: A study of student's concepts. American Journal of Physics, 51, 407-412. doi:10.1119/1.13226

Cox, A. J., Belloni, M., \& Dancy, M. (2003). Teaching thermodynamics with Physlets ${ }^{\circledR}$ in introductory physics. Physics Education, 38, 433-440. doi:10.1088/0031-9120/38/5/309

Dole, J. A., \& Sinatra, G. M. (1998). Reconceptualizing change in the cognitive construction of knowledge. Educational Psychologist, 33, 109-128.

Driver, R., \& Erickson, G. (1983). Theories in action: Some theoretical and empirical issues in the study of students' conceptual frameworks in science. Studies in Science Education, 10, 37-60. doi:10.1080/03057268308559904

Dupin, J. J., \& Johsua, S. (1987). Conceptions of French pupils concerning electric circuits: Structure and evolution. Journal of Research in Science Teaching, 24, 791-806. doi:10.1002/tea.3660240903

Ekici, F., Ekici, E., \& Aydın, F. (2007). Using concept cartoons in diagnosing and overcoming misconceptions related to photosynthesis. International Journal of Environmental \& Science Education, 2, 111-124.

Engelhardt, P. V., \& Beichner, R. J. (2004). Students' understanding of direct current resistive electrical circuits. American Journal of Physics, 72, 98-115. doi:10.1119/1.1614813

Eryilmaz, A. (2002). Effects of conceptual assignments and conceptual change discussions on students' misconceptions and achievement regarding force and motion. Journal of Research in Science Teaching, 39, 1001-1015. doi:10.1002/tea.10054

Fetherstonhaugh, T., \& Treagust, F. D. (1992). Students' understanding of light and its properties: Teaching to engender conceptual change. Science Education, 76, 653-672. doi:10.1002/sce.3730760606

Gilbert, J. K., \& Watts, D. M. (1983). Concepts, misconceptions and alternative conceptions: Changing perspectives in science education. Studies in Science Education, 10, 61-98. doi: $10.1080 / 03057268308559905$

Gregoire, M. (2003). Is it a challenge or a threat? A dualprocess model of teachers' cognition and appraisal process during conceptual change. Educational Psychology Review, 15, 147-179. doi:10.1023/A:1023477131081

Gürses, E., Akdeniz, A. R., \& Atasoy, Ş. (2006). Durgun elektrik konusunda $5 \mathrm{E}$ modeline göre geliştirilen materyallerin öğrenci başarisina etkisi. 7th National Congress of Science and Mathematics Education, Ankara: Gazi University.

Guzetti, B. J., Snyder, T. E., Glass, G. V., \& Gamas, W. S. (1993). Promoting conceptual change in science: A comparative metaanalysis of instructional interventions from reading education and science education. Reading Research Quarterly, 28, 116-159. doi: $10.2307 / 747886$

Hammer, D. (1996). More than misconceptions: Multiple perspectives on student knowledge and reasoning, and an appropriate role for education research. American Journal of Physics, 64, 1316-1325. doi: $10.1119 / 1.18376$

Hasan, S., Bagayoko, D., \& Kelley, E. L. (1999). Misconceptions and the certainty of response index (CRI). Physics Education, 34, $294-$ 299. doi: $10.1088 / 0031-9120 / 34 / 5 / 304$

Heller, M., \& Finley, F. N. (1992). Variable uses of alternative conceptions: A case study in current electricity. Journal of Research in Science Teaching, 29, 259-275. doi:10.1002/tea.3660290306

Hewson, P. W. (1982). A case study of conceptual change in special relativity: The influence of prior knowledge in learning. European Journal of Science Education, 4, 61-78. doi: 10.1080/0140528820040108

Hynd, C., \& Alvermann, D. E. (1986). The role of refutation text in overcoming difficulty with science concepts. Journal of Reading, 29, 440-446.

Jaakkola, T., \& Nurmi, S. (2008). Fostering elementary school students' understanding of simple electricity by combining simulation and laboratory activities. Journal of Computer Assisted Learning, 24, 271-283. doi:10.1111/j.1365-2729.2007.00259.x

Kabapınar, F. (2009). What makes concept cartoons more effective? Using research to inform practice. Education and Science, 34, 104118 .

Keogh, B., Naylor, S., \& Wilson, C. (1998). Concept cartoons: A new perspective on physics education. Physics Education, 33, 219-224. doi:10.1088/0031-9120/33/4/009

Keogh, B., \& Naylor, S. (1999). Concept cartoons, teaching and learning in science: An evaluation. International Journal of Science Education, 21, 431-446. doi:10.1080/095006999290642

Keogh, B., \& Naylor, S. (2000). Teacher and learning in science using concept cartoons: Why Dennis wants to stay in at playtime. Australian Primary and Junior Science Journal, 16, 10-14.

McDermott, L. C., \& Shaffer, P. S. (1992). Research as a guide for curriculum development: An example from introductory electricity. Part I: Investigation of student understanding. American Journal of Physics, 60, 994-1003. doi:/10.1119/1.17003

Mulhall, P., MCKittrick, B., \& Gunstone, R. (2001). A perspective on the resolution of confusion in the teaching of electricity. Research in Science Education, 31, 575-587. doi:/10.1023/A:1013154125379

Pallant, J. (2007). SPSS survival manual-A step by step guide to data analysis using SPSS for windows (3rd ed.). Maidenhead: Open University Press.

Peşman, H., \& Eryılmaz, A. (2010). Development of a three-tier test to assess misconceptions about simple electric circuits. The Journal of Educational Research, 103, 208-222. doi:/10.1080/00220670903383002

Piquette, J. S., \& Heikkinen, H. W. (2005). Strategies reported used by instructors to address student alternate conceptions in chemical equilibrium. Journal of Research in Science Teaching, 42, 1112-1134. doi:/10.1002/tea.20091

Posner, G., J., Srike, K. A., Hewson, P. W., \& Gertzog, W. A. (1982) Accommodation of a scientific conception: Toward a theory of conceptual change. Science Education, 66, 211-227 doi:/10.1002/sce.3730660207

Powell, C. K., \& Kalina, J. C. (2009). Cognitive and social constructivism: Developing tools for an effective classroom. Education, 130, 241-250.

Redish, E. F., Saul, J. M., \& Steinberg R. N. (1998). Student expectations in introductory physics. American Journal of Physics, 66, 212 224. doi:/10.1119/1.18847

Ronen, M., \& Eliahu, M. (2000). Simulation-A bridge between theory and reality: The case of electric circuits. Journal of Computer Assisted Learning, 16, 14-26. doi:/10.1046/j.1365-2729.2000.00112.x

Roth, K. J. (1985). Conceptual change learning and student processing of science texts. Paper presented at the annual meeting of American Research Association, Chicago, April 1985, 46 p.

Sencar, S., \& Eryılmaz, A. (2004). Factors mediating the effect of gen- 


\section{E. TAŞLIDERE}

der on ninth-grade Turkish students' misconceptions concerning electric circuit. Journal of Research in Science Teaching, 41, 603616. doi:/10.1002/tea.20016

Shipstone, D. (1988). Pupils' understanding of simple electrical circuits. Physics Education, 23, 92-96. doi:/10.1088/0031-9120/23/2/004

Shipstone, D. M., von Rhöneck, C., Jung, W., Kärrqvist, C., Dupin, J. J., Joshua, S., \& Licht, P. (1988). A study of students' understanding of electricity in five European countries. International Journal of Science Education, 10, 303-316. doi:/10.1080/0950069880100306

Smit, E. L., Blakeslee, T. D., \& Anderson, C. W. (1993). Teaching strategies associated with conceptual change learning in science. Journal of Research in Science Teaching, 30, 111-126. doi:/10.1002/tea.3660300202

Stephenson, P., \& Warwick, P. (2002). Using concept cartoons to support progression in students' understanding of light. Physics Education, 37, 135-141. doi:/10.1088/0031-9120/37/2/306

Taber, S. K., Trafford, T., \& Quail, T. (2006). Conceptual resources for constructing the concepts of electricity: The role of models, analogies and imagination. Physics Education, 41, 155-160. doi:/10.1088/0031-9120/41/2/006

Taşlidere, E. (2103). The effect of concept cartoon worksheets on students' conceptual understandings of geometrical optics. Education and Science, 38, 144-161.

Treagust, D. F., \& Duit, R. (2008). Conceptual change: A discussion of theoretical, methodological and practical challenges for science education. Cultural Studies of Science Education, 3, 297-328. doi:/10.1007/s11422-008-9090-4

Vosniadou, S. (2007). Conceptual Change and Education. Human Development, 50, 47-54. doi:/10.1159/000097684

Zacharia, Z. C. (2005). The impact of interactive computer simulations on the nature and quality of post graduate science teachers' explanations in physics. International Journal of Science Education, 27, 1741-1767. doi:/10.1080/09500690500239664

Zhou, G. (2010). Conceptual change in science: A process of argumentation. Eurasia Journal of Mathematics, Science \& Technology Education, 6, 101-110. 